\title{
OBITUARY
}

\section{Steven Collins}

\section{1-2018}

\author{
Rupert Gethin
}

Bristol University

Rupert.Gethin@bristol.ac.uk

Professor Steven Collins died unexpectedly on 15 February 2018 during a visit to New Zealand where he was giving a series of lectures as a visiting professor in Buddhist studies at the University of Otago. Steven Collins' premature death he was sixty-six - is a loss to Buddhist studies generally, and a particular loss to the study of Pali Buddhist literature. Steven Collins also served as a member of the Council of the Pali Text Society for two extended periods, first from 1981 to 1993 and then, after a break prompted by his move to the US, from 2006 until his death; his dedication to the Society over so many years will be much missed.

Steven Collins' interest in Theravāda Buddhism and Pali literature began after he had completed his undergraduate studies at Oxford in Latin and Greek (Honours Moderations) and in Philosophy, Politics and Economics, in 1974. His decision to embark on research in Buddhist studies owed something to his friendship with Paul Williams, who at the time was beginning his own research in Madhyamaka under the supervision of B. K. Matilal. Paul Williams introduced Collins to Richard Gombrich, who was then Lecturer in Sanskrit and Pali (but soon to become Boden Professor of Sanskrit), and Steven Collins began his doctoral research under his supervision. The focus of his research was the understanding of the person and self in Pali Buddhist literature; he was awarded the degree of DPhil for his dissertation 'Personal Continuity in Theravāda Buddhism' in 1979. Steven Collins then secured a Junior Research Fellowship at Exeter College, Oxford, and began revising the dissertation for publication. The revised dissertation was published as Selfless Persons: Imagery and Thought in Theravāda Buddhism in 1981, shortly after his appointment as Lecturer in Religious Studies at the University of Bristol (1980). A year later Paul Williams also gained a position at Bristol and together they established a tradition of Buddhist studies at the university that continues.

Like his subsequent scholarship Selfless Persons is informed not only by the disciplines of textual scholarship but by broad intellectual interests - literary, philo-

1. This obituary was first published in Journal of the Pali Text Society, 34 (2021), 1-10. 
sophical, sociological, and anthropological. One of the most important aspects of Collins' approach to reading Pali texts already evident in Selfless Persons was the focus on imagery, in this instance house, vegetation, and river imagery. Indeed, an emphasis on the need to take the imaginative world of Pali texts seriously in the context of understanding their systematic doctrine was to become a feature of his approach to reading Pali literature.

Selfless Persons sets out to explore and understand how the doctrine of 'not self' works — philosophically, psychologically, emotionally, and socially — within a broad corpus of Pali texts. While he does not ignore questions related to the development of the doctrine, he has little time for those - past, present, and no doubt future - who seek to save the Buddha from what they perceive as the unwanted consequences of the doctrine of anattan by claiming that the Buddhist tradition has misrepresented him on the issue. ${ }^{2}$ Selfless Persons has become perhaps the standard treatment of the doctrine of 'not self' (anattan) in early Buddhist literature, although for some his refusal to engage with the possibility that the Buddha did not teach what the texts say he taught means it is tainted by a form of Theravāda orthodoxy. I suspect that Collins would respond that his concern was with understanding the reality of Buddhist doctrine, not some long lost imaginary doctrine.

Steven Collins' interest in matters related to the Buddhist understanding of the person continued, resulting in a number of further publications. In particular his article 'A Buddhist Debate about the Self and Remarks on Buddhism in the Work of Derek Parfit and Galen Strawson' (1997) presented his own translation of a portion of the then untranslated twelfth-century Upāsakajanālañkāra, arguing for its relevance to modern philosophical debates. ${ }^{3}$

But in the 1980s and 1990s Collins' scholarly interests began to shift towards a broader exploration of what he referred to as the cultural logic of asceticism: what role does a group who are in some sense wishing to escape society play in society? This would eventually result in the publication of his second monograph, Nirvana and Other Buddhist Felicities in 1998. In the meantime he published a number of articles that contributed directly or indirectly to this project, including a study of the neglected notion of the good friend 'Kalyānamitta and Kalyānamittată' (1987), an annotated translation of the Aggaññasutta (1992), the results of his initial reflections on nirvana ('Nirvāna, Time, and Narrative', 1992), a significant contribution to the discussion of the orality of ancient Pali literature ('Notes on Some Oral Aspects of Pali Literature', 1992), as well as engaging in an exchange with Andrew Huxley on the social-contract theory of Buddhist kingship.

2. See in particular 'Self and Non-Self in Early Buddhism', Numen, 29 (1982), 251-271, a review article of Joaquín Pérez-Rémon, Self and Non-Self in Early Buddhism (The Hague: Mouton, 1980).

3. See also 'Buddhism in Recent British Philosophy and Theology', Religious Studies, 21 (1985), 47593; 'Categories, Concepts or Predicaments? Remarks on Mauss's Use of Philosophical Terminology', in The Category of the Person: Anthropology, Philosophy, History, edited by Michael Carrithers, Steven Collins and Steven Lukes (Cambridge: Cambridge University Press, 1986), pp. 46-82; 'What Are Buddhists Doing When They Deny the Self?', in Religion and Practical Reason, edited by Frank Reynolds and D. Tracy (Albany, NY: State University of New York Press, 1994), pp. 59-86. 
In addition, in September 1987 Collins had given the second I. B. Horner Memorial Lecture with the title 'On the Very Idea of the Pali Canon'. This was subsequently published in the Journal of Pali Text Society (1990). Here he pointed out that the notion that 'the Buddha's word' (buddhavacana) comprised a precisely defined set of texts appears to be peculiar to the Theravāda tradition of Buddhism. He went on to argue that the fixing of the Pali canon was related to a more general strategy of self-definition and self-legitimation on the part of Theravāda monks of the ancient Mahāvihāra that also involved the production of standard commentaries as well as chronicles setting out the history of its lineage (vamsa).

In 1987 Steven Collins moved from Bristol to North America, initially to a oneyear position at Indiana University Bloomington. It was shortly before his move to America that I met him for the first time when he acted as one of the examiners for my doctoral dissertation at Manchester. What I remember from this first encounter is his intellectual integrity based in a genuine quest for understanding. While Collins did not immediately resign from his position at Bristol, leaving open the possibility of a return, it was clear to his friends and colleagues that this was never his preferred option and that the possibilities offered by academic life in North America attracted him.

In 1989 Collins moved to Concordia University in Montreal, and then in 1991 to the University of Chicago, where he joined the Department of South Asian Languages and Civilizations and was to remain for the rest of his academic career. In the preface to Nirvana and Other Buddhist Felicities, he acknowledges the influence of 'the extraordinarily stimulating and challenging intellectual milieu at Chicago' (p. xv). Certainly this second monograph, published sixteen years after his first, impresses by the breadth and ambition of its intellectual vision, which encompasses philosophy, historiography, anthropology, sociology and literary theory. Given the place this book occupies in Steven Collins scholarly oeuvre it is worth saying more about it. ${ }^{4}$

Nirvana and Other Buddhist Felicities is a study of the vision of 'happiness' revealed in the Pali 'imaginaire', a term he adopts from French historiography. The problem Collins seeks to explore is not simply the metaphysics of nirvana. It is rather how the Theravāda Buddhist vision of happiness, which in advocating a life of asceticism seems to run counter to people's ordinary aspirations, becomes the inspiration of civilizations across South and Southeast Asia. At seven hundred pages it is a substantial work, comprising an extended introduction on 'Buddhism and civilizational history', lengthy considerations first of nirvana as the ultimate 'happiness' of Theravāda Buddhism (164 pages), and then of Buddhist visions of other, relative, forms of happiness (the ideal society, life in the heaven worlds), as well as appendices of translations of Pali texts.

Collins suggests that the problem that has often preoccupied modern Buddhist scholarship — whether nirvana is a form of super-existence or mere non-existence — is a pseudo problem created by accepting 'Buddhist conceptual presuppositions

4. See also Rupert Gethin, review of Steven Collins, Nirvana and Other Buddhist Felicities, Contemporary Buddhism, 2 (2001), 121-127. 
but not the conclusions which Buddhists have drawn from them'; here he highlights in particular the failure to respect 'the silences which they have preserved', which are part of the production of meaning. In fact, he suggests, Theravāda Buddhist texts are quite clear about the nature of nirvana (p. 97). But for Collins making sense of nirvana in Buddhist terms is not enough; he tasks himself with making sense of it in his own scholarly terms (p. 205). To this end the book is dedicated to demonstrating how 'nirvana was thought, as a concept, an image, and as a syntactic element of closure, structural and narrative, in the Buddhist discourse of felicity, implicit in any and every form of imagined well-being' (p. 25).

The ambition and length of Nirvana and other Buddhist Felicities mean that it is not always an easy book, and no doubt this is one of the reasons that prompted him to publish an abridged version in 2010 (Nirvana: Concept, Imagery, Narrative), over ten years after the original publication. Some will inevitably feel that the richness of Collins' intellectual framework is not always to their taste and at times indigestible. Nonetheless, there is no doubting that Collins' intellectual achievement is considerable: he has much to say about various aspects of the study of Buddhism and Pali literature that deserves careful consideration. Perhaps his most lasting contribution is the manner in which he explores Buddhist imagery and narrative literature as a way of deepening an understanding of systematic doctrine, insisting that we need to take texts seriously as redacted wholes rather than treat them as crudely thrown together. In this way he attempts to go beyond 'the dour-faced and humorless positivism with which these texts are so often read' (p.494). In the final chapter of Nirvana and Other Buddhist Felicities Collins turned to the Vessantarajätaka as a work of literature, getting to the heart (in more than one sense) of what he wants to say: here we find the full spectrum of Buddhist happiness - from the beauty of this world to the final and sublime peace of nirvana - narrated in a work of literature that confronts the reality of the painful emotions involved in renouncing the joys of family life in the quest for nirvana. The need to consider the literary aspects of Pali texts generally and with reference to the Vessantarajātaka was an issue Collins returned to in his 2003 essay 'What is literature in Pali?' as well as in the collection of essays he edited, Readings of the Vessantara Jātaka (2016).

In the early 2000s Collins turned his scholarly energies to issues related to Theravāda Buddhism and gender. This led to a series of invited lectures entitled 'Civilisation et la femme célibataire' delivered at L'École pratique des hautes études in Paris in 2006 (published as a monograph in 2011), ${ }^{5}$ as well as several other articles. ${ }^{6}$

In 2011, with Juliane Schober, he launched the Theravāda Civilizations Project as a way of supporting collaborative exchanges among scholars working on different dimensions of the Theravāda civilizations of South and Southeast Asia. The project facilitated a number of workshops in the US and Asia resulting in a volume edited

5. Civilisation et femmes célibataires dans le bouddhisme en asie du sud et du sud-est: une "étude de genre" (Paris: Éditions du Cerf, 2011).

6. Including 'Remarks on the Third Precept: Adultery and Prostitution in Pāli Texts', Journal of the Pali Text Society, 29 (2007), 263-284; and (with Justin McDaniel) 'Buddhist 'Nuns' (Mae Chi) and the Teaching of Pali in Contemporary Thailand', Modern Asian Studies, 44 (2010), 1373-1408.

(C) Equinox Publishing Ltd 2021

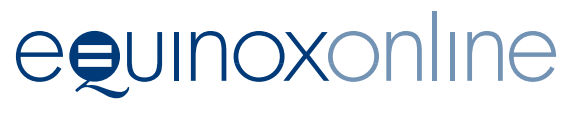


with Schober, Theravāda Buddhist Encounters with Modernity (2017). In the last decade of his life, he also published a number of insightful focused studies, such as 'Remarks on the Visuddhimagga; and on Its Treatment of the Memory of Former Dwelling(s) (pubbenivāsānussatiñāna)' (2009) and 'Madness and Possession in Pāli Texts' (2014). But it is his contribution to an edited book that eventually appeared shortly after his death that reveals the direction his scholarship was heading.

'Some Remarks on Hadot, Foucault, and Comparisons with Buddhism' (2018) returns to the broad philosophical themes and the issues of cross-cultural comparisons that are also apparent in Selfless Persons and Nirvana and Other Buddhist Felicities. The specific question at stake here is the possibility of a cross-cultural comparison of 'spiritual exercises' and 'technologies of self' as envisioned by Pierre Hadot and Michel Foucault. The question is approached with Collins' characteristic concerns — rigour and precision in the use of language when translating (in this case the works of Hadot and Foucault, as well as Pali texts), the need to set systems of ideas in their practical, social and institutional contexts, the importance of careful and close reading. This chapter anticipates themes that are developed in a final monograph, published posthumously on the basis of an unfinished manuscript, Wisdom as a Way of Life: Theravāda Buddhism Reimagined (2020). In this final work Collins presents something of his own vision of how the academic and scholarly study of Theravāda Buddhism might become something more than merely academic and itself contribute to a modern 'philosophy as a way of life'. Once again, he emphasizes the importance of narrative thought for understanding the imaginaire of Theravāda Buddhism, focusing in particular on the literary dimensions of the jātaka tales.

The intellectual ambition and range of Steven Collins' work mean that he is sometimes a difficult author. But there can be no doubt that his scholarly output represents a very considerable contribution to the study of Pali literature, not only in his interpretation and understanding of specific texts, but also in what he has to say about how we should approach reading Pali texts in order to make sense of them. On both accounts his work deserves reading and rereading. Steven Collins' scholarship is carried out within an intellectual framework that combines the methods and insights of a number of disciplines in a genuine quest for understanding from a perspective of genuine humanity. He cared deeply about Pali literature and devoted his career to trying to show that what it had to say was important. ${ }^{7}$

\section{Select bibliography of works by Steven Collins}

\section{Books}

Selfless Persons: Imagery and Thought in Theravāda Buddhism (Cambridge: Cambridge University Press, 1982).

Nirvana and Other Buddhist Felicities: Utopias of the Pali Imaginaire (Cambridge: Cambridge University Press, 1998).

7. For further reflections on Steven Collins' scholarly legacy, see Charles Hallisey, 'Exploring the Buddhist Middle Way From a Middle Ground: In Memoriam Steven Collins’, Sophia, 57 (2018), 203-206, and the preface (Dan Arnold), the editor's introduction (Justin McDaniel), and the afterword (Charles Hallisey) of Steven Collins, Wisdom as a Way of Life (2020). 
A Pali Grammar for Students (Chiang Mai: Silkworm Books, 2006).

Nirvana: Concept, Imagery, Narrative (Cambridge: Cambridge University Press, 2010).

Civilisation et femmes célibataires dans le bouddhisme en asie du sud et du sud-est: une 'étude de genre' (Paris: Éditions du Cerf, 2011).

Self and Society: Essays on Pali Literature and Social Theory, 1988-2010 (Chiang Mai: Silkworm, 2014).

Wisdom as a Way of Life: Theravāda Buddhism Reimagined, edited by Justin McDaniel with a preface by Dan Arnold and an afterword by Charles Hallisey (New York: Columbia University Press, 2020).

\section{Edited books}

The Category of the Person: Anthropology, Philosophy, History, edited by Michael Carrithers, Steven Collins and Steven Lukes (Cambridge: Cambridge University Press, 1986).

Readings of the Vessantara Jātaka, edited by Steven Collins (New York: Columbia University Press, 2016).

Theravāda Buddhist Encounters with Modernity, edited by Juliane Schober and Steven Collins (London and New York: Routledge, 2017).

\section{Articles}

'Self and Non-Self in Early Buddhism'. Numen, 29 (1982): 251-271.

'Buddhism in Recent British Philosophy and Theology'. Religious Studies, 21 (1985): 475-493.

'Categories, Concepts or Predicaments? Remarks on Mauss's Use of Philosophical Terminology'. In The Category of the Person: Anthropology, Philosophy, History, edited by Michael Carrithers, Steven Collins and Steven Lukes (Cambridge: Cambridge University Press, 1986), pp. 46-82.

'Kalyānamitta and Kalyānamittatā'. Journal of the Pali Text Society, 11 (1987): 51-72.

'Louis Dumont and the Study of Religions'. Religious Studies Review, 15 (1989): 14-21.

'On the Very Idea of the Pāli Canon'. Journal of the Pali Text Society, 15 (1990): 89-126.

'Nirvāna, Time, and Narrative'. History of Religions, 31 (1992): 215-246.

'Notes on Some Oral Aspects of Pali Literature'. Indo-Iranian Journal, 35 (1992): 121-135.

'Problems With Pacceka-Buddhas'. Religion, 22 (1992): 271-278.

'The Discourse on What is Primary (Aggañña-Sutta): An Annotated Translation'. Journal of Indian Philosophy, 21 (1993): 301-393.

'The Story of the Elder Māleyya'. Journal of the Pali Text Society, 18 (1993), 65-96.

‘What Are Buddhists Doing When They Deny the Self?' In Religion and Practical Reason, edited by Frank Reynolds and D. Tracy (Albany, NY: State University of New York Press, 1994), pp. 59-86.

'The Lion's Roar on the Wheel-Turning King: A Response to Andrew Huxley's “the Buddha and the Social Contract"'. Journal of Indian Philosophy, 24 (1996): 421-446.

(With Andrew Huxley) 'The Postcanonical Adventures of Mahāsammata'. Journal of Indian Philosophy, 24 (1996): 623-48.

'The Body in Theravāda Buddhist Monasticism'. In Religion and the Body, edited by Sarah Coakley (Cambridge: Cambridge University Press, 1997), pp. 185-204.

'A Buddhist Debate About the Self: And Remarks on Buddhism in the Work of Derek Parfit and Galen Strawson'. Journal of Indian Philosophy, 25 (1997): 467-493.

'Of Death and Trees', Times Literary Supplement, 4972 (1998), 30.

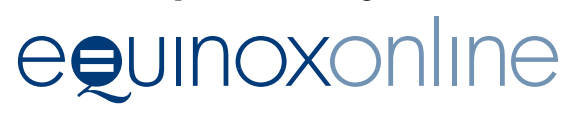


'What is Literature in Pali?', in Literary Cultures in History: Reconstructions from South Asia, edited by Sheldon Pollock (Berkeley: University of California Press, 2003), pp. 649-688.

'Remarks on the Visuddhimagga; and on Its Treatment of the Memory of Former Dwelling(s) (pubbenivāsānussatiñāna)'. Journal of Indian Philosophy, 37 (2009): 499-532.

(With Justin McDaniel) 'Buddhist "Nuns" (Mae Chi) and the Teaching of Pali in Contemporary Thailand'. Modern Asian Studies, 44(6) (2010): 1373-1408.

'Madness and Possession in Pāli Texts'. Buddhist Studies Review, 31(2) (2014): 195-214.

'Some Remarks on Hadot, Foucault, and Comparisons With Buddhism'. In Buddhist Spiritual Practices: Thinking with Pierre Hadot on Buddhism, Philosophy, and the Path, edited by David Fiordalis (Berkeley, CA: Mangalam Press, 2018), pp. 21-69. 